\title{
Effect of addition of clay minerals on the properties of epoxy/polyester powder coatings
}

\author{
Natanael Relosi ${ }^{1 *}$, Oscar Almeida Neuwald ${ }^{1}$, Ademir José Zattera², Diego Piazza², Sandra Raquel Kunst ${ }^{1}$ \\ and Eliena Jonko Birriel ${ }^{1}$
}

\author{
${ }^{1}$ Laboratório de Corrosão e Proteção Superficial - LCOR, Universidade de Caxias do Sul - UCS, \\ Caxias do Sul, $R S$, Brasil \\ ${ }^{2}$ Laboratório de Polímeros - LPOL, Universidade de Caxias do Sul - UCS, Caxias do Sul, RS, Brasil \\ *nrelosi@ucs.br
}

\begin{abstract}
Powder coatings have been used for coating metal substrates in industrial applications. The incorporation of nanofillers as muscovite mica and montmorillonite (MMT) can improve the properties of the coatings. The objective of this study is to develop, apply and characterize a hybrid powder coating ( $30 \%$ epoxy $/ 70 \%$ polyester) adding nanofillers in concentrations of 2, 4 and $6 \mathrm{phr}$ separately in a twin screw extruder. The characterization of the coatings was performed by thermal, mechanical and chemical analysis. The incorporation of clay into the polymer increased the surface roughness resulting in a diffuse reflection of incident light and on a gloss reduction. The muscovite mica presented a lamellar structure, constituted by a set of overlapping parallel plates. The morphology analysis showed that the MMT presented irregular agglomerates resulting in inferior mechanical properties to coatings with muscovite mica. In the salt spray test, all samples showed high corrosion protection, around 850 hours.
\end{abstract}

Keywords: epoxy/polyester resin, montmorillonite, muscovite mica, powder coating.

\section{Introduction}

One of the most used metal substrate protection systems in industry is the powder coating, because it has excellent mechanical and chemical resistance and corrosion properties. Moreover, these coatings are free from volatile organic compounds (VOCs). One of the advantages of the powder coatings is their preparation and application, as the electrostatic spraying enables the reuse of the material that has not adhered on the surface of the substrate ${ }^{[1-6]}$.

The mechanical, thermal and chemical properties of the coatings are influenced mainly by the type of resin that is used. The polyurethane, acrylic, silicone, polyester and epoxy ${ }^{[4,7]}$ are among the most commonly used commercial resins.

The epoxy-based coating has a high performance which provides stability in a corrosive environment, good adhesion properties on metallic substrates as well as good mechanical and thermal properties, but it has a low resistance to natural weathering ${ }^{[1,8,9]}$. The polyester-based coating presents an excellent stability to heat and resistance to light and to natural weathering, and an excellent finishing appearance with respect to gloss and leveling ${ }^{[1,10]}$. Hybrid powder coatings are formulated from balanced proportions of two kinds of resin. The hybrid coatings (epoxy/polyester) are aimed at reconciling the weathering resistance characteristics and the action of UV rays with the chemical resistance and mechanical characteristics ${ }^{[8-10]}$.

To improve the mechanical, thermal and chemical properties of the powder coatings, nanofillers are incorporated in the chemical composition of the coatings. Clay minerals, such as muscovite mica and montmorillonite (MMT) are among the nanometer-scaled materials that can be used. MMT clays generally provide better mechanical properties and improve the thermal stability, with an elevated heat distortion temperature and flame retardant ability ${ }^{[1]}$. Studies with muscovite mica, which is a layered structure with a high degree of crystallographic orientation, show an improvement in barrier properties such as gas permeability, chemical resistance and flammability. Another feature is the low cost of these clays and thus a smaller load combined with a high level of performance can be used ${ }^{[12-14]}$.

Recent researches found that the use of clay concentrations up to $10 \%{ }^{[12,15,16]}$ produces significant improvements in the thermal, mechanical and chemical properties of powder coatings ${ }^{[13,15-19]}$. Thus, the objective of this work is to produce, apply and characterize a hybrid powder coating by separately adding mica muscovite and MMT $30 \mathrm{~B}$ at concentrations of 2, 4 and 6 phr, evaluating the thermal, mechanical, chemical and morphological properties resulting from the addition of these clay minerals.

\section{Materials and Methods}

\subsection{Materials}

The materials used in the formulation of the powder coating used in this work were the polyester resin Crylcoat ${ }^{\mathrm{TM}}$ 1783-0 from Cytec and the epoxy resin GT 7220 from Huntsman. The spreading agent was supplied by Estron Chemical Inc. (trade name Resiflow ${ }^{\mathrm{TM}} \mathrm{PV}-60$ ); benzoin 
(surfactant) was provided by Datiquim Chemicals Ltd; the polyethylene wax was provided by Clariant; the muscovite mica clay was provided by Lamil Lage Minérios and MMT 30B, provided by Southern Clay Products Inc., (Cloisite $\left.{ }^{\circledR} 30 \mathrm{~B}\right)$.

The identification of the samples is shown in Table 1.

\subsection{Surface preparation}

The metal substrates AISI 1010 carbon steel with dimensions of $70 \times 120 \times 0.65 \mathrm{~mm}$ were mechanically prepared with sandpaper with the following grain sizes: $\# 320$, \#400 and \#600, sequentially. They were subsequently subjected to a phosphating pre treatment with zinc phosphate by the dipping method. This pre treatment is performed to improve the adhesion of powder coatings.

The phosphating process included the degreasing stages using the commercial product Saloclean $679 \mathrm{RZ}$ at $60^{\circ} \mathrm{C}$ for 10 minutes. This product is composed of a mixture of anionic, nonionic surfactants, phosphates and silicates. It is recommended for the degreasing of iron and steel parts. Completely removes greases and oils leaving the substrate clean to receive further treatment. In refiner stage the commercial product Salocoloide 507 was used at room temperature $\left(25^{\circ} \mathrm{C}\right)$ for 1 minute. This product is formulated based on sodium salts and titanium complexes. It was developed to produce on the metal surface a micro crystalline layer of titanium salts, which will serve as the nucleus for the deposition of the zinc phosphate grains. In the phosphating stage the commercial products Salofos 715 and 903 Salotex were used at $30^{\circ} \mathrm{C}$ for 10 minutes. It is a product that has the function of depositing a micro crystalline layer of zinc phosphate on ferrous metals, increasing the resistance to corrosion and providing greater adhesion. It is formulated based on zinc salts, organic and inorganic acids and special inhibitors. The product which was used for the passivation was the Salomix 307, used at room temperature for 90 seconds. It is a product whose purpose is to level the crystals of the phosphate layer by increasing the corrosion resistance of the treated parts. After that, the samples were dried in an oven for 10 minutes at $100^{\circ} \mathrm{C}$.

\subsection{Development of the powder coating}

The clays (muscovite mica and MMT 30B) were dried at $60{ }^{\circ} \mathrm{C}$ for 8 hours. All of the constituents of the powder coating were mixed manually, with the incorporation of $2 \mathrm{phr}, 4 \mathrm{phr}$ and $6 \mathrm{phr}$ of the two clays separately, using the commercial formulations of the hybrid powder coating as shown in Table 2.

In the epoxy/polyester hybrid system curing (crosslinking) occurs through chemical reaction between the resins transforming the linear system into a three-dimensional structure system, ie, infusible, with high solvent resistance, excellent adhesion and flexibility, impact resistance and to chemical agents.

The epoxy resin acts as a curing agent for the polyester resin. Depending on the choice of resins and their relative proportions, the properties of the hybrid will be between those of the pure epoxy and the pure polyester. The presence of the epoxy resin leaves this type of resin susceptible to calcination by solar exposition ${ }^{[1,6]}$. Figure 1 present the
Table 1. Identification of hybrid powder coatings.

\begin{tabular}{ccc}
\hline Identification & Filler content (phr) & Clays \\
\hline TH/0 & No filler & - \\
TH/2/MICA & 2 & Muscovite mica \\
TH/4/MICA & 4 & \\
TH/6/MICA & 6 & \\
TH/2/MMT 30B & 2 & \\
TH/4/MMT 30B & 4 & MMT 30B \\
TH/6/MMT 30B & 6 & \\
\hline
\end{tabular}

Table 2. Formulation of hybrid powder coatings.

\begin{tabular}{cc}
\hline Material & Composition (g) \\
\hline Polyester resin & 700 \\
Epoxy resin & 300 \\
Spreading agent & 10 \\
Surfactant & 5 \\
Polyethylene wax & 5 \\
Muscovite mica / MMT 30B & 20,40 and 60 \\
\hline
\end{tabular}

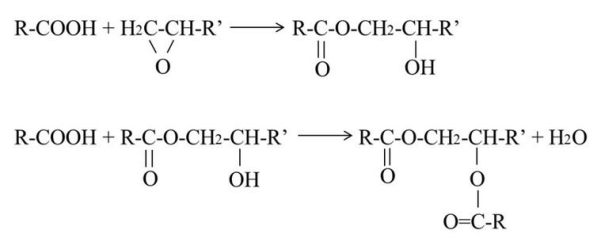

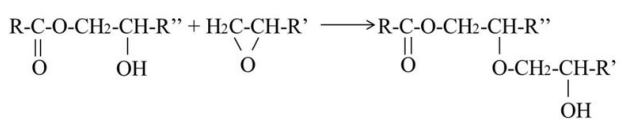

Figure 1. Chemical reactions for the curing process of the epoxy/polyester coatings (a) reaction of carboxyl group with epoxy group (b) reaction of ester of hydroxyl group with carboxyl group (c) reaction of hydroxyl group with epoxy group.

chemical reactions responsible for the curing process of the epoxy/polyester coatings.

The reaction between the carboxyl and glycidyl groups is catalyzed by basic catalysts (tertiary amines and quaternary ammonium salts); when the ratio between these groups is 1:1, the reaction (a) is favored. However, when there is an excess of glycidyl groups, reaction (c) occurs in a significant way even in the absence of acid catalysis; the reaction (b) occurs when there is an excess of carboxyl groups on the glycidy ${ }^{[1]}$.

The mixture of the constituents was then processed in a double-screw co-rotating extruder MH-COR-20-32 MH Equipment Ltd under the following conditions: Speed of $200 \mathrm{rpm}$ and $70^{\circ} \mathrm{C}$ (zone 1), $80^{\circ} \mathrm{C}$ (zone 2) and $90^{\circ} \mathrm{C}$ (zone 3-9). After the extrusion the material was manually capped and granulated in the form of chips. The chips were milled in a Cadence knife grinder (model: MDR301) and after they were sieved in a 200 mesh Tyler sieve $(75 \mu \mathrm{m})$.

\subsection{Powder coating application}

The phosphatated mild steel panels were painted by electrostatic spray, with a corona TCAECO TECNOAVANCE model 301 spray, using an electric generator with a voltage 
output of up to $100 \mathrm{kV}$, a current $60 \mathrm{~mA}$, and a pressure air stream speed of 1 psi. Thereafter, the panels were placed in a MDH DeLeo Laboratories greenhouse for 15 minutes at $200{ }^{\circ} \mathrm{C}$ to obtain the curing of the coating.

\subsection{Characterization of the coatings}

The TGA analysis was performed on a Shimadzu TGA-50 device with a pre-defined temperature range from 25 to $500{ }^{\circ} \mathrm{C}$ under an inert $\mathrm{N}_{2}$ atmosphere, and 500 to $900^{\circ} \mathrm{C}$ in an artificial synthetic air atmosphere, at a rate of $10^{\circ} \mathrm{C} \cdot \mathrm{min}^{-1}$ and a flow of $50 \mathrm{~mL} \cdot \mathrm{min}^{-1}$ of $\mathrm{N}_{2}$. The DSC test was performed on a Shimadzu DSC-60 device with a variation in temperature from 25 to $275{ }^{\circ} \mathrm{C}$ at a rate of $10{ }^{\circ} \mathrm{C} \cdot \mathrm{min}^{-1}$ and a flow $50 \mathrm{~mL} \cdot \mathrm{min}^{-1}$ of $\mathrm{N}_{2}$. The FTIR analysis was performed with a Thermo Scientific Nicolet 10 iS equipment using $\mathrm{KBr}$ pellets in the spectral range of 400 to $4000 \mathrm{~cm}^{-1}$. A total of 32 scans with a resolution of $1 \mathrm{~cm}^{-1}$ was performed.

The scanning electron microscopy by field emission (SEM-FEG) of the powders were held under a microscope TESCAN MIRA 3, with an acceleration voltage of $15 \mathrm{kV}$. The samples were fixed in metal brackets (stubs) with the aid of a conductive adhesive (a ribbon) and covered with a thin layer of gold by plating.

The thickness measurement of the hybrid powder coatings was carried by the magnetic method as per the ASTM D7378-10 standard $^{[20]}$ with the thickness gauge instrument ELCOMETER ${ }^{\circledR} 345$ for metallic substrates. The pencil hardness test was performed according to the ASTM D3363-05E2 standard ${ }^{[21]}$. The tests were performed with a set of pencils with different hardness of graffiti. The pencil hardness value was regarded as the hardness of the pencil that did not cut or caused grooves in the film. The adhesion of the coating to the metal substrate was evaluated by the method B of ASTM D3359-09 ${ }^{[22]}$. The brightness analysis was performed according to the ASTM D523-08 standard ${ }^{[23]}$, using the Multi Gloss meter 268 plus, from Konica Minolta, at an angle of $60^{\circ}$. The coating flexibility test was carried out following the method described in the conical mandrel test from ASTM D522-93 ${ }^{[24]}$, using the Gardner Conical Mandrel BYK device. The impact resistance test was conducted in a Heavy-Duty Impact Tester BYK Gardner equipment, according to the ASTM D2794-93 standard ${ }^{[25]}$, using an impact force of $50 \mathrm{~kg} \cdot \mathrm{cm}$ both for the direct impact as to the reverse.

The salt spray test followed the ASTM B117 the standard ${ }^{[26]}$, for 850 hours in a closed Mark Bass USX-6000/2012 chamber.

\section{Results and Discussion}

The TGA and DTG thermograms obtained with the analysis of the hybrid powder coating and a commercial formulation of coatings incorporating 2, 4 and $6 \mathrm{phr}$ of muscovite mica and MMT 30B are shown in Figure 2 and Figure 3.

It is observed that the muscovite mica has a high thermal stability and little weight loss (approximately $5 \%$ ). On the other hand, it is clear that the MMT 30B shows a marked weight loss from $178^{\circ} \mathrm{C}$. According to Paiva et al. ${ }^{[27]}$ the decomposition process MMT has three steps: the first and the second relates to the decomposition of the surfactant $\left(180\right.$ to $\left.384.5^{\circ} \mathrm{C}\right)$ and the third stage is related to the dehydroxylation of the clay $\left(556\right.$ to $636.4{ }^{\circ} \mathrm{C}$ ). This may be related to the fact that muscovite mica has the characteristic of promoting the formation of transitional coal, which begins to degrade only at high temperatures ${ }^{[28]}$. In addition, chemically, muscovite mica presents a differential in relation to the other clay minerals, since its interlayer cations are not interchangeable under environmental conditions; only surface cations can be exchanged at room temperature ${ }^{[29]}$. The hybrid powder coatings showed two mass loss events, the first observed event in an inert $\mathrm{N}_{2}$ atmosphere $\left(350{ }^{\circ} \mathrm{C}\right.$ to $\left.500^{\circ} \mathrm{C}\right)$ and the second corresponds to the effect of changing the atmosphere of the synthetic air from the equipment, which accelerates the resin degradation process $\left(500{ }^{\circ} \mathrm{C}\right.$ to $\left.600{ }^{\circ} \mathrm{C}\right)$. A higher weight loss of the samples is associated with the degradation of the polymeric matrix, which starts at about $350{ }^{\circ} \mathrm{C}^{[30]}$. A similar behavior was observed by Bharadwaj et al. ${ }^{[31]}$, who evaluated the influence of the addition of different clay concentrations on the morphology and properties of a polyester based nanocomposite and noted that even with
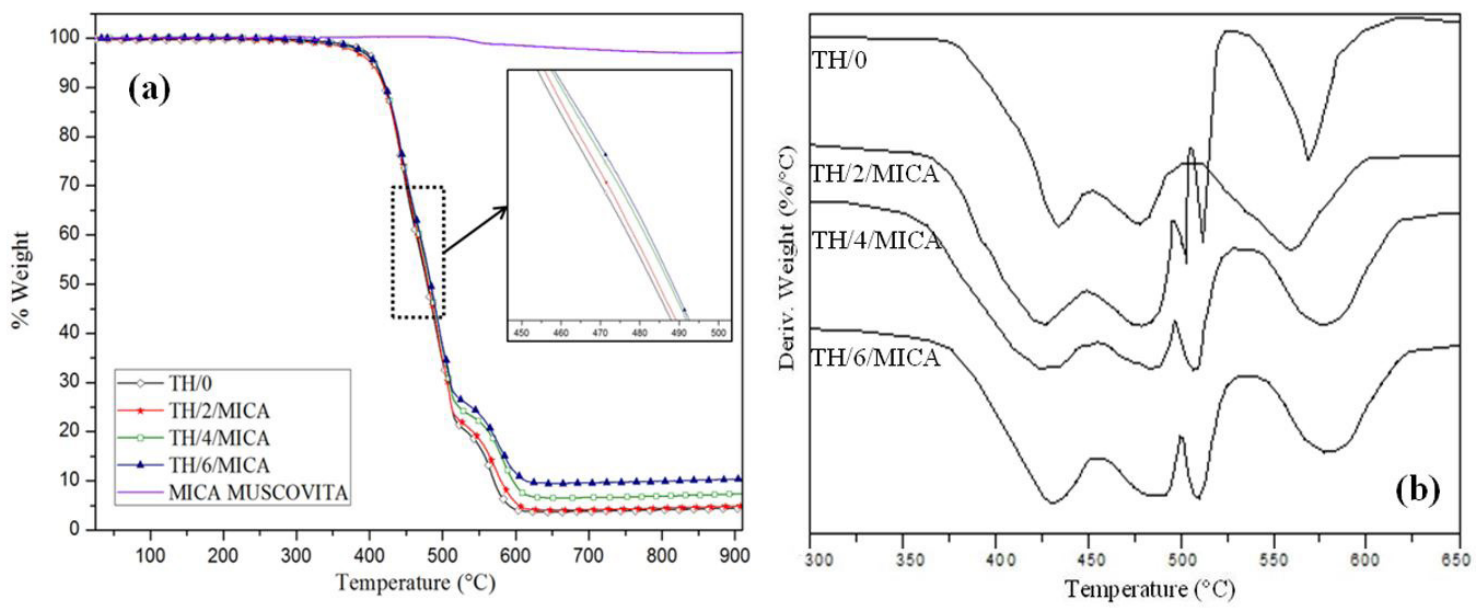

Figure 2. Thermograms of (a) TGA and (b) DTG of the hybrid powder coatings with the addition of different levels of muscovite mica. 

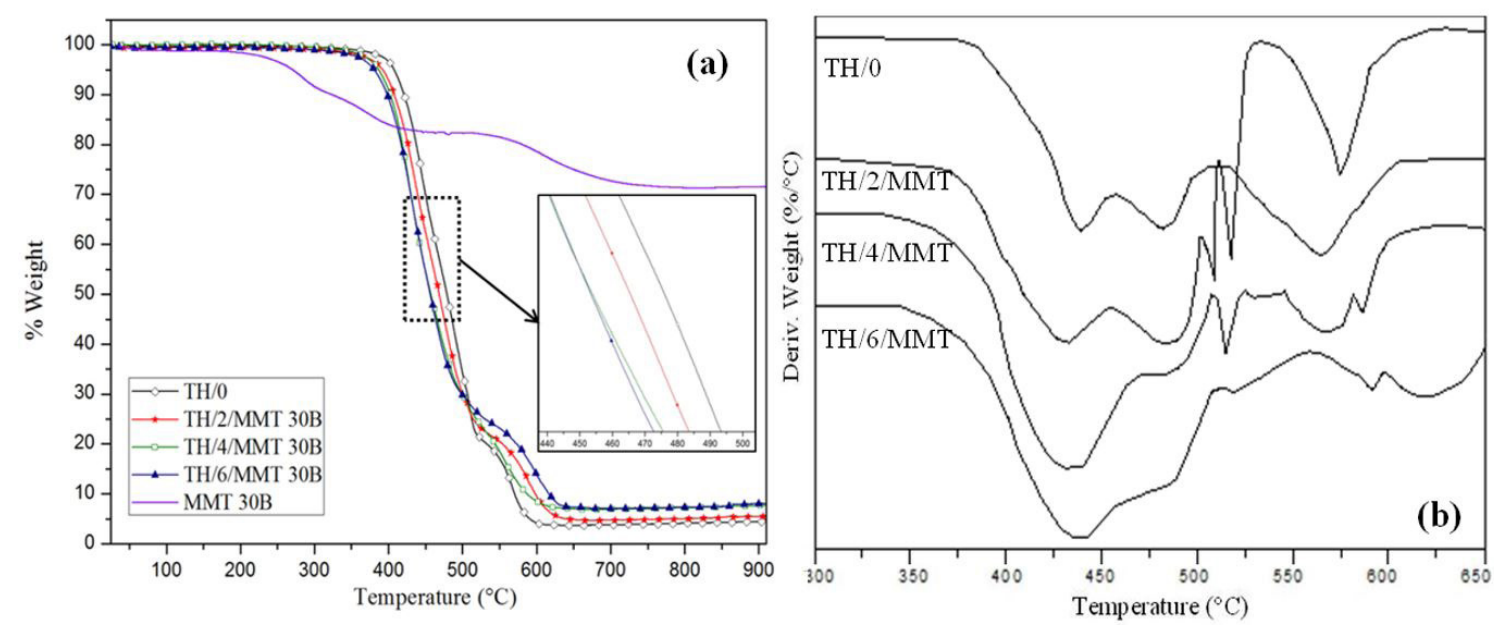

Figure 3. Thermograms of (a) TGA and (b) DTG of the hybrid powder coatings with the addition of different levels of MMT 30B.

a good dispersion of clay in the polymer matrix, there is a slight acceleration of the thermal degradation of the sample in the range from 25 to $400{ }^{\circ} \mathrm{C}$ due to the presence of hydroxyl groups in the organic modifier which provides a supply of oxygen.

Table 3 shows the data obtained from the TGA and DTG curves and also the residue content of the hybrid powder coatings containing different levels of muscovite mica and MMT 30B.

From Table 3, it is possible to see that all coatings, except $\mathrm{TH} / 6 / \mathrm{MMT} 30 \mathrm{~B}$, showed reduction in $\mathrm{T}_{\max }$. This result was found by other authors who justified this behavior in different ways. Oliveira $\mathrm{Jr}^{[32]}$. observed that the incorporation of the modified clay in the polypropylene did not significantly improve the thermal stability of the microcomposite and attributed this fact to the low dispersion of the clay in the polymer matrix and formation of agglomerates. Ollier et al. ${ }^{[33]}$ observed that the incorporation of the modified clay did not significantly influence the degradation temperatures of the nanocomposites to the organic modifier present in the MMT structure.

Thus, the lower thermal stability presented by the clay-containing coatings may be related to the form of dispersion and the interaction of the clay-mineral with the polymer matrix. In the case of MMT 30B coatings, this reduction may be associated to the organic modifier decomposition of the clay, accelerating the loss of mass. In the case of coatings incorporating muscovite mica, the reduction can be attributed to the catalytic effect caused by the clay and the dispersion of the filler. In this way, it is clear that the thermal stability of the coatings decreased due to the addition of clay minerals.

The increase of muscovite mica and MMT 30B content incorporated in the powder coating resulted in an increase in the final residue as shown in Table 3. In addition, it was observed that the TH/6/MICA and TH/6/MMT 30B coatings showed the highest levels of residue due to the presence of the inorganic phase of clays. This was expected, given that an increase in the percentage of clay incorporated in the
Table 3. Residue content and maximum temperature of degradation of the hybrid powder coatings.

\begin{tabular}{ccc}
\hline Sample & $\mathbf{T}_{\text {max }}$ & Residue content (\%) \\
\hline TH/0 & $439^{\circ} \mathrm{C}$ & 4.4 \\
TH/2/MICA & $430^{\circ} \mathrm{C}$ & 4.8 \\
TH/4/MICA & $426^{\circ} \mathrm{C}$ & 7.3 \\
TH/6/MICA & $428^{\circ} \mathrm{C}$ & 10.4 \\
TH/2/MMT 30B & $432^{\circ} \mathrm{C}$ & 5.5 \\
TH/4/MMT 30B & $432^{\circ} \mathrm{C}$ & 7.5 \\
TH/6/MMT 30B & $440^{\circ} \mathrm{C}$ & 8.1 \\
\hline
\end{tabular}

coatings means an increase of the thermal stability of the polymer matrix, thus restricting the output of the volatile formed by the decomposition of the polymer. In addition, this behavior may also be associated with the greater dispersion of this clay in the resin, increasing the pathway for transport of oxygen and volatile compounds through the coating film ${ }^{[30,34]}$.

The DSC thermograms of the hybrid powder coatings with the addition of clay are shown in Figure 4.

This analysis shows two significant thermal events. The first refers to the glass transition temperature $\left(\mathrm{T}_{\mathrm{g}}\right)$ and the second to the crosslinking temperature $\left(\mathrm{T}_{\text {reticulation }}\right)$. The dispersion of inorganic particles (lamellar silicates) in reaction medium strongly affects the mass and heat transfer, making the system less reactive, as can be observed with the decrease of $\mathrm{T}_{\mathrm{g}}$. A dispersant could be added to the ink formulation in order to assist the interaction between the polymeric matrix with the muscovite mica and MMT 30B particles

However, the hybrid inks with the addition of MMT $30 \mathrm{~B}$ showed an increase of $\mathrm{T}_{\text {reticulation }}$ from $171.7^{\circ} \mathrm{C}$ to $187.3^{\circ} \mathrm{C}$ (Figure 3b). This may be related to the difficulty of molecular mobility due to the strong interaction that occurs between the polymer matrix with nanoparticles of MMT 30B, as suggested by other authors ${ }^{[10,35,36]}$. 
Figure 5 shows the FTIR spectrum of the pure hybrid coating and the coating containing mica muscovite and MMT 30B.

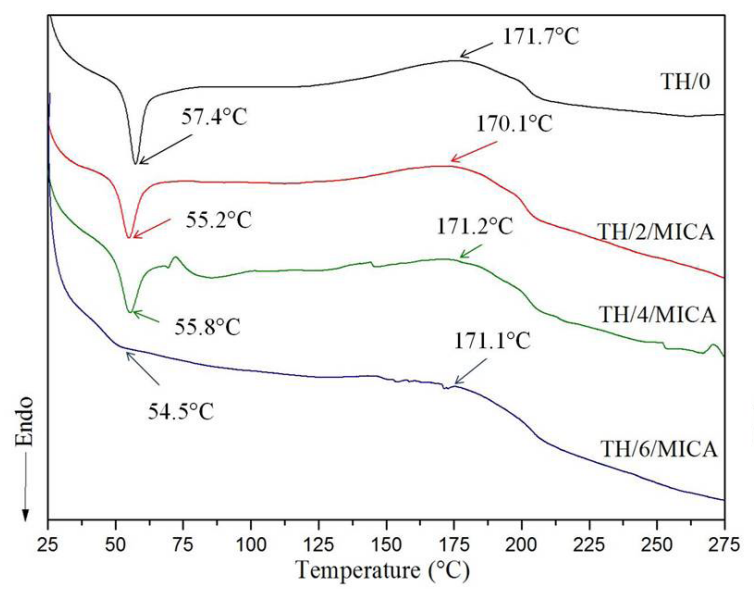

(a)
The characteristic absorption bands of the polyester/TGIC structure (triglycidylisocyanurate curing agent) were observed in $1720 \mathrm{~cm}^{-1}$ due to stretching $\mathrm{C}=\mathrm{O}, 2969 \mathrm{~cm}^{-1}$, and

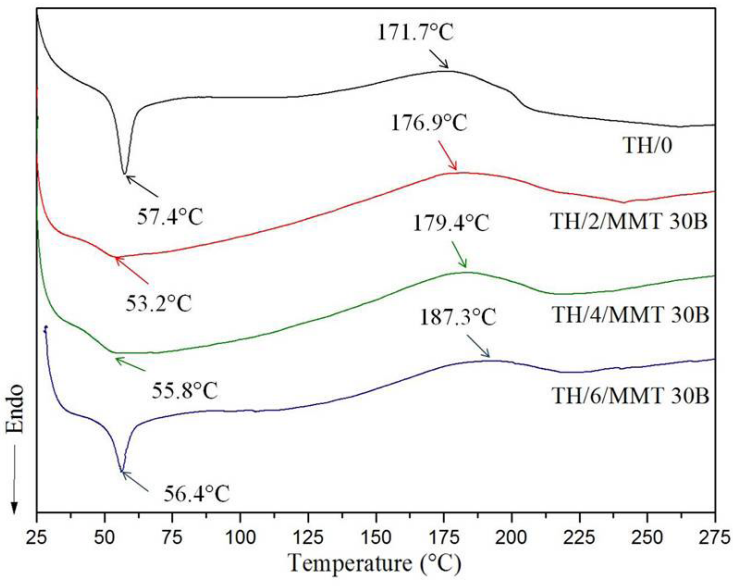

(b)

Figure 4. DSC thermograms of the hybrid powder coatings with different levels of (a) muscovite mica and (b) MMT 30B.

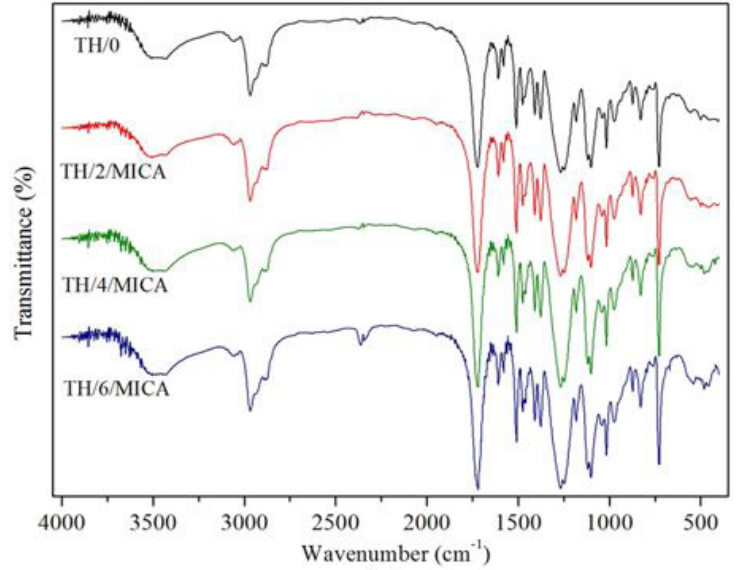

(a)

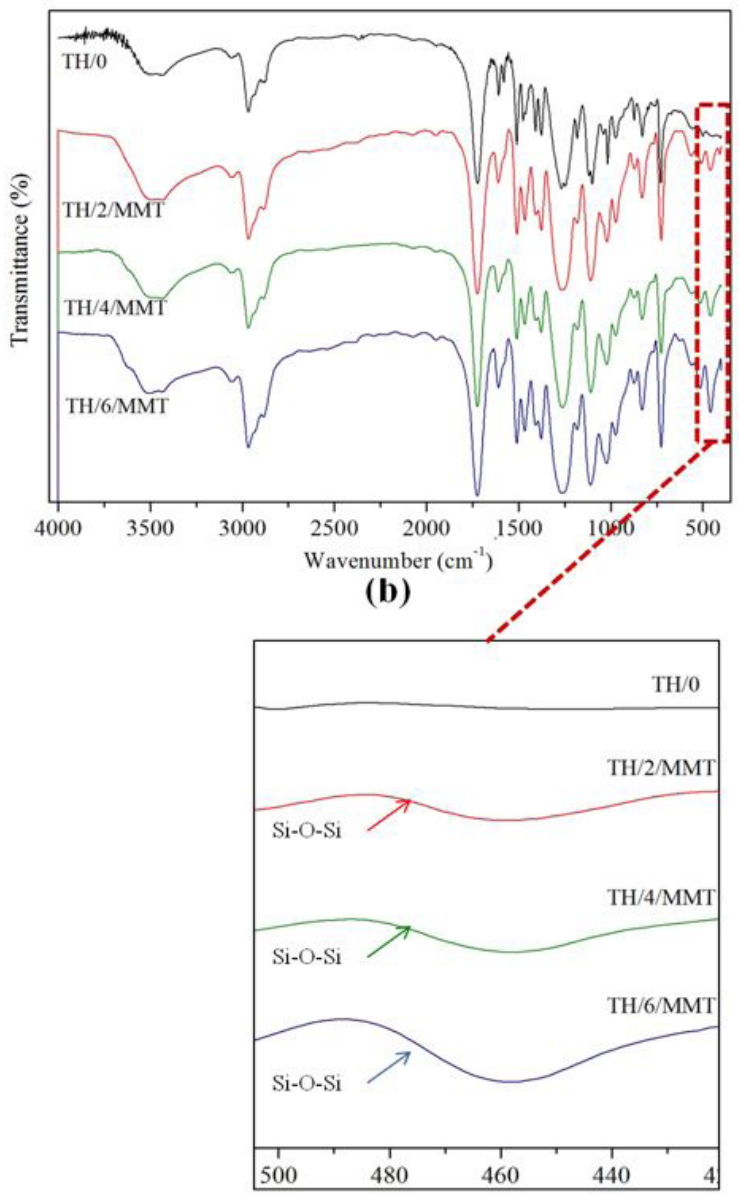

Figure 5. FTIR spectrum for powder coatings by incorporating (a) muscovite mica and (b) MMT 30B. 
$2891 \mathrm{~cm}^{-1}$ due to the asymmetric and symmetric stretching of the $\mathrm{CH}_{2}$ group. For coatings containing muscovite mica, the presence of nanoparticles in the polymer matrix introduced no new peaks in the FTIR spectrum. However, as the concentration of MMT 30B increased, it was observed that the intensity of the band at $460 \mathrm{~cm}^{-1}$ related to the Si-O-Si links became more evident as was expected. Comparing the spectra of other hybrid coatings with the clay minerals, it was observed that there is an overlapping in most of the absorption bands.

Figure 6 shows the morphological analysis of muscovite mica clay obtained by SEM-FEG. Through this analysis, it was observed that muscovite mica clay showed a morphology constituted by overlapping a set of parallel plates, a lamellar structure, as expected. This morphological structure of muscovite mica was also observed by other authors ${ }^{[37-39]}$.

The interactions between the polymer matrix and the reinforcing fillers favor the aggregation and incorporation of the same. Inorganic particles, such as clays, tend to aggregate into a polymer matrix independent of the type or size of the material. The tendency to fillers aggregation increases with the decrease of the particle size and this is due to the increase of the contact surface ${ }^{[40,41]}$.

Figure 7 shows the morphology of MMT 30B. It was found that the clay mineral shows irregular agglomerates
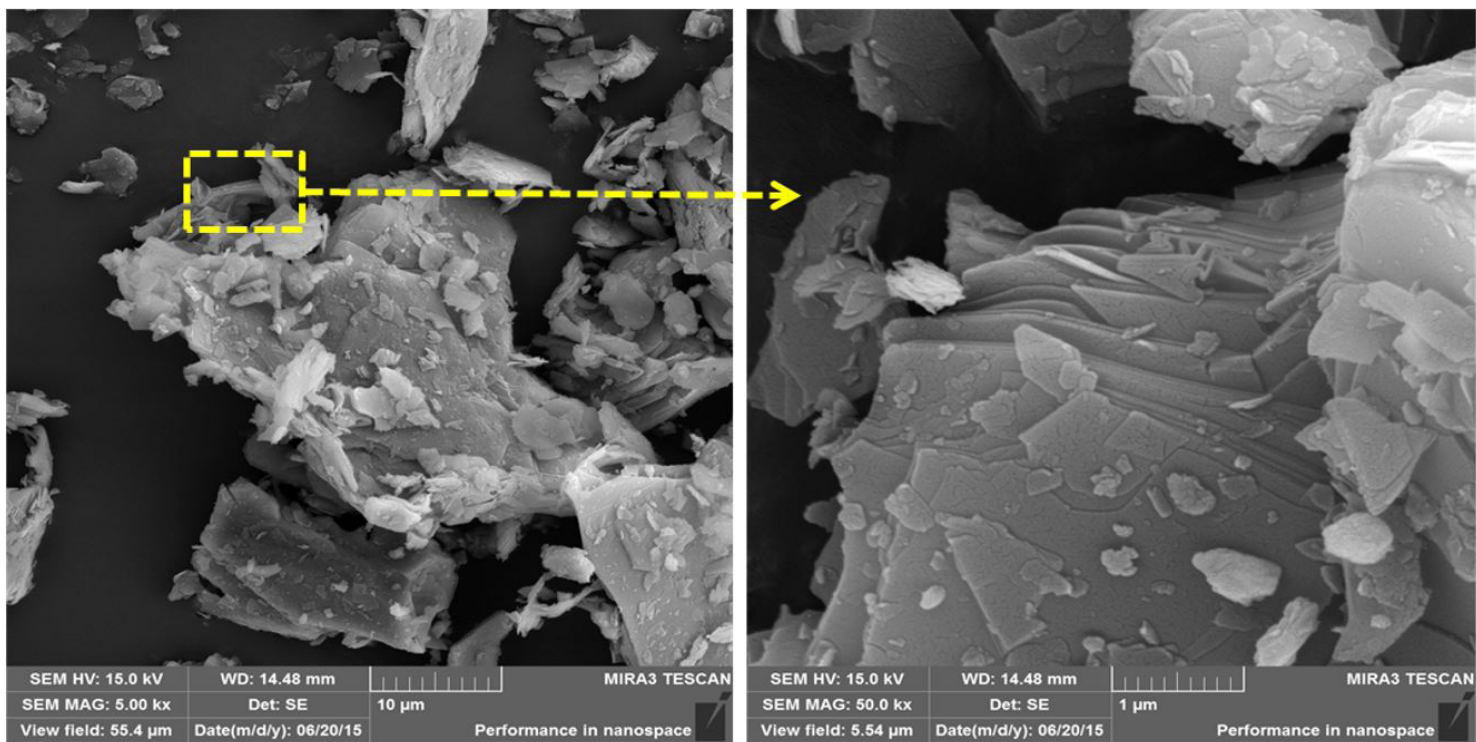

Figure 6. Micrographs obtained by SEM-FEG of muscovite mica clay in different magnitudes.
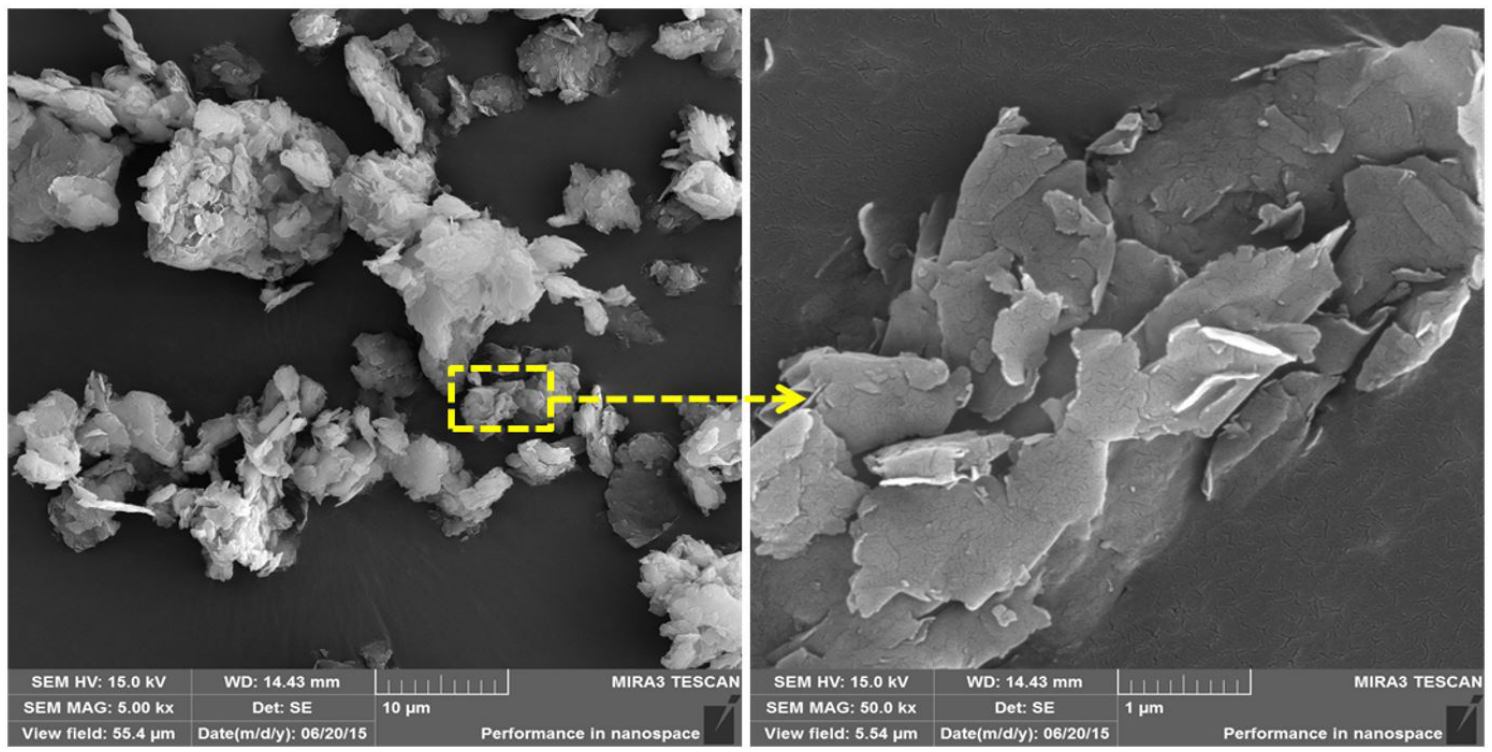

Figure 7. Micrographs obtained by SEM-FEG of MMT 30B clay in different magnitudes. 
constituted by relatively flat sheets. According to Wang et al. ${ }^{[42]}$ the surfaces of the $\mathrm{SiO}_{2}$ particles have a large number of hydroxyl groups due to the hydrogen bonding to the nanoparticles through Van der Waals forces that causes aggregation of nanoparticles. Due to the strong tendency to agglomerate, the $\mathrm{SiO}_{2}$ particles are very difficult to achieve a homogeneous dispersion in the polymer. Coatings with such agglomerates generally exhibit inferior mechanical properties.

When modified clays are used, the intercalation ability of the polymer depends on the length of the surface modifier. The larger the modifier, the greater the space between the layers of clay and therefore the greater the probability of intercalation. The smaller the modifier, the lower its miscibility with the polymer ${ }^{[43]}$.

The MMT clays in the natural state have hydrophilic character and when added in a polymer matrix they tend to form agglomerates, not dispersing. This is due to the intensity of the ionic forces existing between the layers of clay, where the clay surface energy will be higher than that of the polymer ${ }^{[44-46]}$.

Modification of MMT aims to improve the compatibility and dispersion of the clay in the polymer matrix. The method most commonly employed in the modification of MMT clay is the ion exchange of the inorganic cations present in its structure by cationic surfactants, such as quaternary ammonium salts ${ }^{[47,48]}$. This process produces a clay with organophilic character and with greater interlamellar space. The presence of the ammonium salts in the interlamellar space weakens the interaction between the layers of the clay, facilitating their intercalation and/or exfoliation in the polymeric matrix ${ }^{[47-49]}$. However, since quaternary ammonium salts undergo degradation at temperatures close to the processing temperature of many polymer resins, the thermal instability of organophilic clay becomes a strong limitation in the processing of polymer/clay nanocomposites ${ }^{[50-51]}$.

In Figure 7, agglomerates of MMT 30B were observed. This morphology denotes that the use of this clay was not efficient to promote a strong interaction with the polymer matrix.

In the XRD analysis it is observed based on the first characteristic peak of muscovite mica at $8.80^{\circ}$ (2theta), basal spacing identified as $\mathrm{d}_{001}$ correspond to $1.01 \mathrm{~nm}$. Evaluation of basal spacing $\mathrm{d}_{001}$ of such phyllosilicate incorporated into the coating did not evince modification (presenting the same value of $1.01 \mathrm{~nm}$ ), indicating that it was not possible to identify neither exfoliation nor intercalation of the polymeric matrix into the mineral lamellae with such analysis $^{[52-54]}$. The graph and values obtained in the XRD analysis are shown in Figure 8 and Table 4.

In the diffractogram of the coating with MMT 30B (Figure 9) it can be observed that, based on the first characteristic peak of montmorillonite at $4.95^{\circ}$ (2theta), the basal spacing $\mathrm{d}_{001}$ is $1.79 \mathrm{~nm}$. When evaluating the basal spacing $\mathrm{d}_{001}$ of this clay when incorporated in the coating, the values are verified and shown on Table 5. Thus, it was verified the occurrence of intercalation of the polymeric matrix within the galleries, possibly with clays dispersed randomly. It was also verified that higher clay concentrations resulted in smaller spacing, indicating that with lower contents the exfoliated phase is prevailing, and that for higher concentrations intercalation occurs ${ }^{[16]}$.
The results of measurement of the thickness of the coating layer, the pencil hardness and the adhesion test are shown in Table 6.

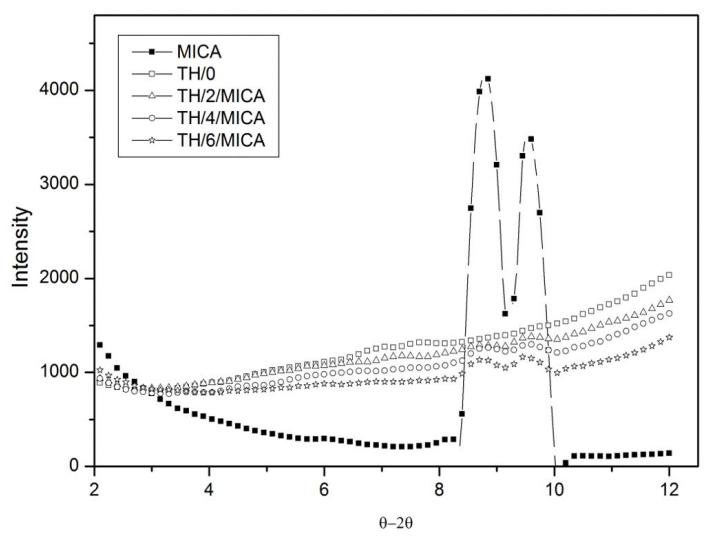

Figure 8. X-ray diffraction of muscovite mica of hybrid powder coatings before curing with different muscovite mica contents.

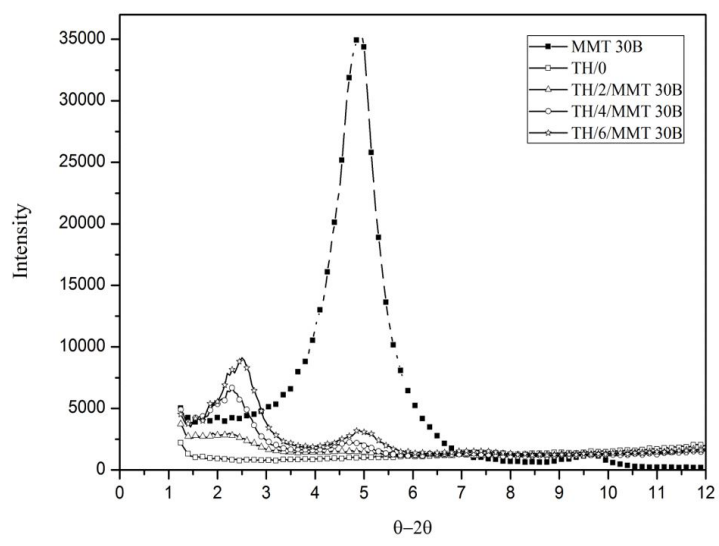

Figure 9. Overlap of the MMT 30B X-ray diffractograms of the hybrid powder coatings, before curing, with different levels of MMT 30B.

Table 4. Basal spacing values " $\mathrm{d}_{001}$ " calculated by Bragg's law for hybrid powder coatings before curing with addition of different muscovite mica contents.

\begin{tabular}{ccc}
\hline Sample & $\mathbf{2 \theta}\left(^{\circ}\right)$ & Distance $\left.\mathbf{d}_{\mathbf{0 0 1}} \mathbf{( n m}\right)$ \\
\hline TH/0 & 8.8 & 1.01 \\
TH/2/MICA & 8.8 & 1.01 \\
TH/4/MICA & 8.8 & 1.01 \\
TH/6/MICA & 8.8 & 1.01 \\
\hline
\end{tabular}

Table 5. Basal spacing values " $\mathrm{d}_{001}$ " calculated by Bragg's law for hybrid powder coatings before curing with addition of different levels of MMT 30B.

\begin{tabular}{ccc}
\hline Sample & $\mathbf{2 \theta}\left(^{\circ}\right)$ & Distance $\mathbf{d}_{\mathbf{0 0 1}}(\mathbf{n m})$ \\
\hline TH/0 & 4.95 & 1.79 \\
TH/2/MMT 30B & 1.9 & 4.65 \\
TH/4/MMT 30B & 2.3 & 3.84 \\
TH/6/MMT 30B & 2.5 & 3.54 \\
\hline
\end{tabular}


It was observed that the coatings exhibit little difference in the value of the average thickness among the samples. This fact is important to compare the mechanical and chemical resistance results that are presented below.

The incorporation of the clay resulted in an increased pencil hardness of the coatings. The TH/ 0 powder coating showed a lower pencil hardness being classified as $\mathrm{HB}$, the coating TH/4/MMT 30B showed a pencil hardness of $2 \mathrm{H}$, and other coatings exhibited a hardness of $\mathrm{H}$. The increase in the hardness of the powder coatings may be due to the presence of particles of clay on the surface ${ }^{[55]}$. Lv et al. ${ }^{[56]}$ verified the increase in pencil hardness in nanocomposites with added clay and attributed this result to a greater compatibility and to the high density of crosslinking between the clay and the polymer matrix. They observed that the filler loading increases the hardness of the coating due to increased film stiffness.

The appearance of the hybrid coatings containing different levels of muscovite mica clay and MMT 30B applied on carbon steel after the adhesion test is shown in Figure 10.

All coatings showed an adhesion of $5 \mathrm{~B}$. These results demonstrate the formation of coatings with a high mechanical resistance with respect to the grip factor, which is of extreme importance to the anticorrosive properties of the coatings.

Table 6. Thickness, pencil hardness and adhesion testing results of hybrid powder coatings.

\begin{tabular}{lccc}
\hline \multicolumn{1}{c}{ Samples } & $\begin{array}{c}\text { Average } \\
\text { thickness }(\boldsymbol{\mu m})\end{array}$ & $\begin{array}{c}\text { Pencil } \\
\text { hardness }\end{array}$ & $\begin{array}{c}\text { Adherence } \\
\text { rating }\end{array}$ \\
\hline $\mathrm{TH} / 0$ & $77.7 \pm 7.3$ & $\mathrm{HB}$ & $5 \mathrm{~B}$ \\
$\mathrm{TH} / 2 / \mathrm{MICA}$ & $74.8 \pm 6.5$ & $\mathrm{H}$ & $5 \mathrm{~B}$ \\
$\mathrm{TH} / 4 / \mathrm{MICA}$ & $68.7 \pm 6.8$ & $\mathrm{H}$ & $5 \mathrm{~B}$ \\
$\mathrm{TH} / 6 / \mathrm{MICA}$ & $74.7 \pm 6.3$ & $\mathrm{H}$ & $5 \mathrm{~B}$ \\
$\mathrm{TH} / 2 / \mathrm{MMT} 30 \mathrm{~B}$ & $77.4 \pm 6.1$ & $\mathrm{H}$ & $5 \mathrm{~B}$ \\
$\mathrm{TH} / \mathrm{MMT} 30 \mathrm{~B}$ & $68.9 \pm 7.2$ & $2 \mathrm{H}$ & $5 \mathrm{~B}$ \\
$\mathrm{TH} / \mathrm{MMT}$ 30B & $76.1 \pm 6.3$ & $\mathrm{H}$ & $5 \mathrm{~B}$ \\
\hline
\end{tabular}

The adhesion of the hybrid powder coatings indicate that the phosphating pretreatment enhances the adhesion of the coating to the metal substrate. The results presented in the adhesion test confirm that the presence of MMT 30B and muscovite mica clays did not affect the adhesion characteristics of the hybrid coating to the metal substrate. Similar results were found by Piazza et al. ${ }^{[57]}$ to evaluate the incorporation of MMT 30B in an epoxy based coating. Bagherzadeh and Mahdavi ${ }^{[58]}$ and Navarchian et al. ${ }^{[59]}$ also found that the presence of clay does not alter the adhesion of the coating to the substrate. According to Garcia et al. ${ }^{[60]}$, the adhesion properties may be associated with hydroxyl groups produced in the curing reaction of the material and its ability to establish hydrogen bonds between the coating and the substrate.

Figure 11 shows the results of the gloss analysis with its standard deviations.

The increase of muscovite mica and MMT 30B content in the powder coating formulation caused a reduction of gloss. The sample with 2 phr of MMT 30B did not influence the gloss of the powder coating, and a similar value to the coating without the addition of fillers was obtained. The samples with $6 \mathrm{phr}$ of muscovite mica and MMT 30B showed less than 80 G.U. for gloss, and were thus classified as semi-gloss varnish, which according to industry standards are the ones in the 50-80 G.U. range. The gloss value for the remaining samples were above the required industry standard for high-gloss varnishes (G.U. > G.U. 80).

These results may be associated with the formation of clay agglomerates which intersect the surface finish and increase the surface roughness resulting in a diffuse reflection of incident light and on a gloss reduction ${ }^{[61]}$. This result corroborates the data observed by Wicks et al. ${ }^{[62]}$, who report that the size as well as the concentration of the filler particles significantly affects the characteristics of the coating as mechanical properties, barrier properties, corrosion and especially gloss.

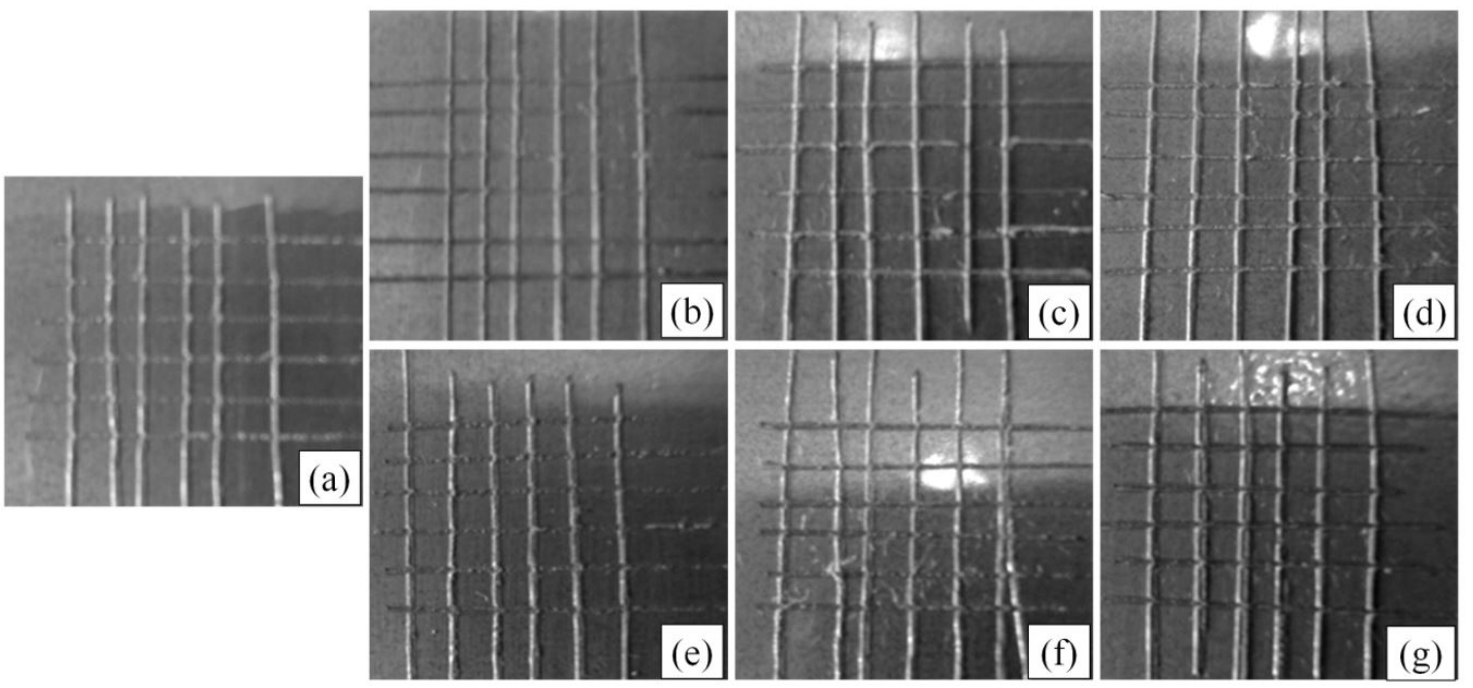

Figure 10. Results of adhesion test performed with the hybrid powder coatings (a) TH/0, (b) TH/2/MICA, (c) TH/4/MICA, (d) TH/6/MICA, (e) TH/2/MMT 30B, (f) TH/4/MMT 30B and (g) TH/6/MMT 30B. 
Figure 12 shows the result of the conical mandrel flexibility test performed on carbon steel panels coated with the hybrid powder coating containing different amounts of muscovite mica and MMT 30B.

A qualitative analysis of samples submitted to the flexibility test indicated the absence of cracks or peeling for coatings with the incorporation of muscovite mica.

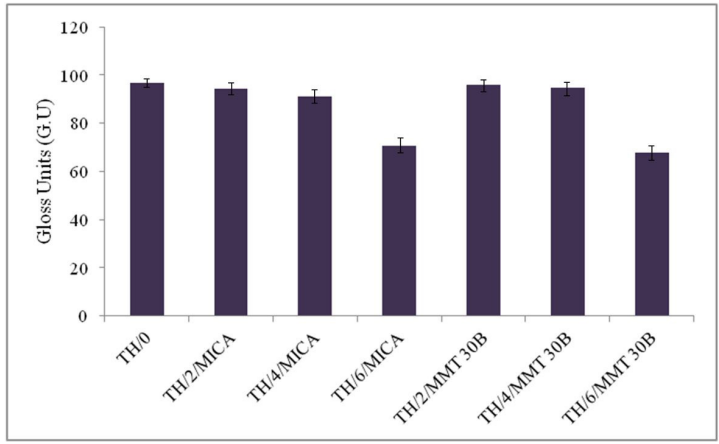

Figure 11. Gloss analysis of hybrid powder coatings with different levels of muscovite mica and MMT 30B.
This was due to the adhesion between the coating and the metal substrate and the cohesion between the coating molecules. The muscovite mica additions in the tested concentrations did not affect the flexibility of the coating. Panels with the coating incorporating MMT 30B clay in different concentrations showed failures in flexible hybrid coating. This was due to the greater amount of clay, which favors the formation of MMT agglomerates, as observed in the morphological test (Figure 7). The increase in the MMT content in the formulation of the coatings makes them more fragile, associated with decreased molecular mobility restrictions imposed by the merging of the molecules of the hybrid resin inside the clay mineral ${ }^{[57]}$.

Figure 13 shows the appearance of the coated metal substrates with hybrid powder coatings free of clay and with the addition of 2, 4 and $6 \mathrm{phr}$ of muscovite mica and MMT 30B which underwent a resistance review of rapid deformation (impact)

Based on a visual analysis of the samples, it can be seen that the sample without addition of clay mineral and the TH/4/MICA sample showed resistance to impact. The best performance, coating, TH/4/MICA, can be associated to an increase in cohesive forces in the coating caused by
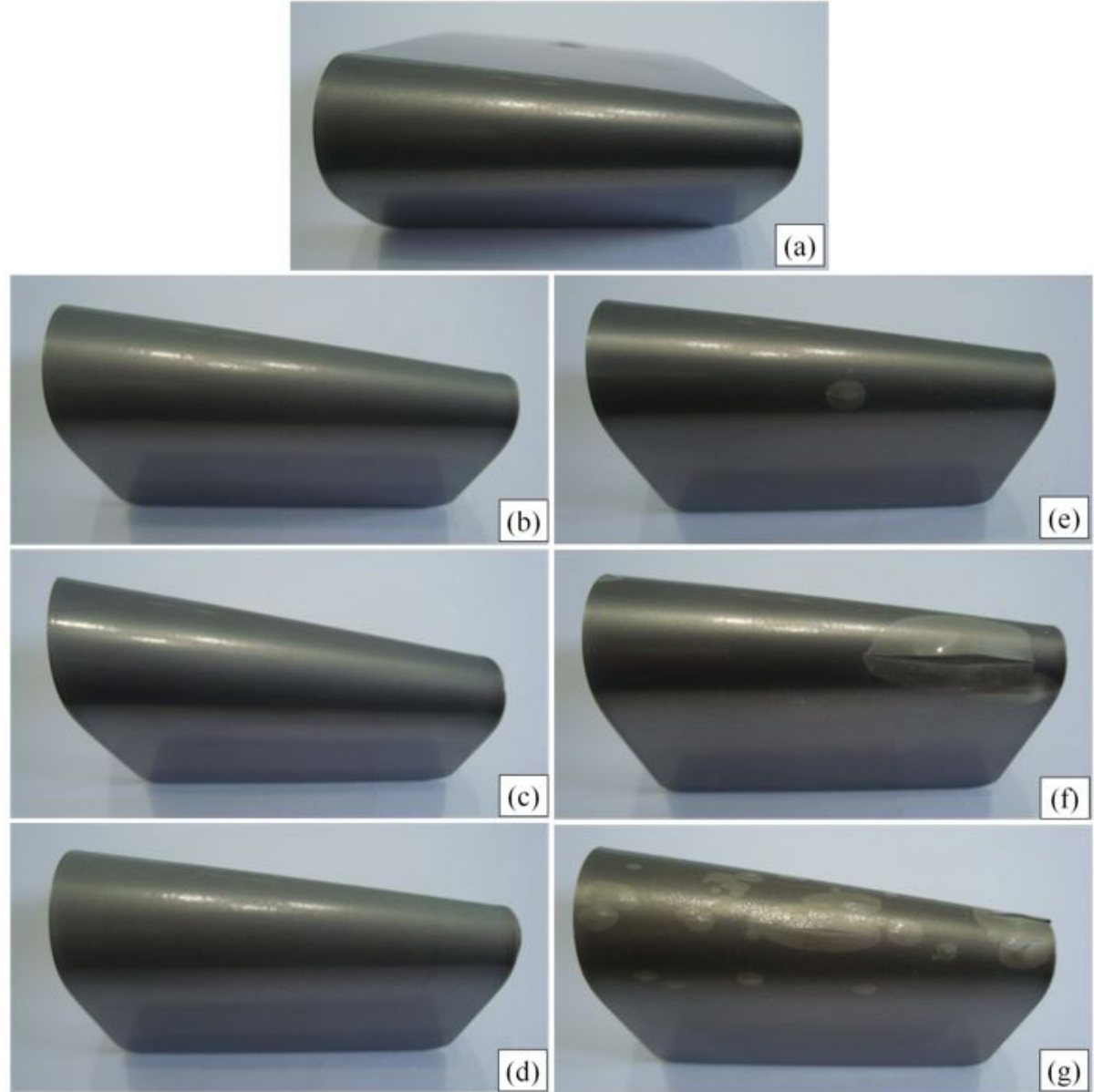

Figure 12. Images analysis result of the flexibility of hybrid powder coatings applied on carbon steel after curing: (a) TH/0, (b) TH/2/MICA, (c) TH/4/MICA, (d) TH/6/MICA, (e) TH/2/MMT 30B, (f) TH/4/MMT 30B e (g) TH/6/MMT 30B. 


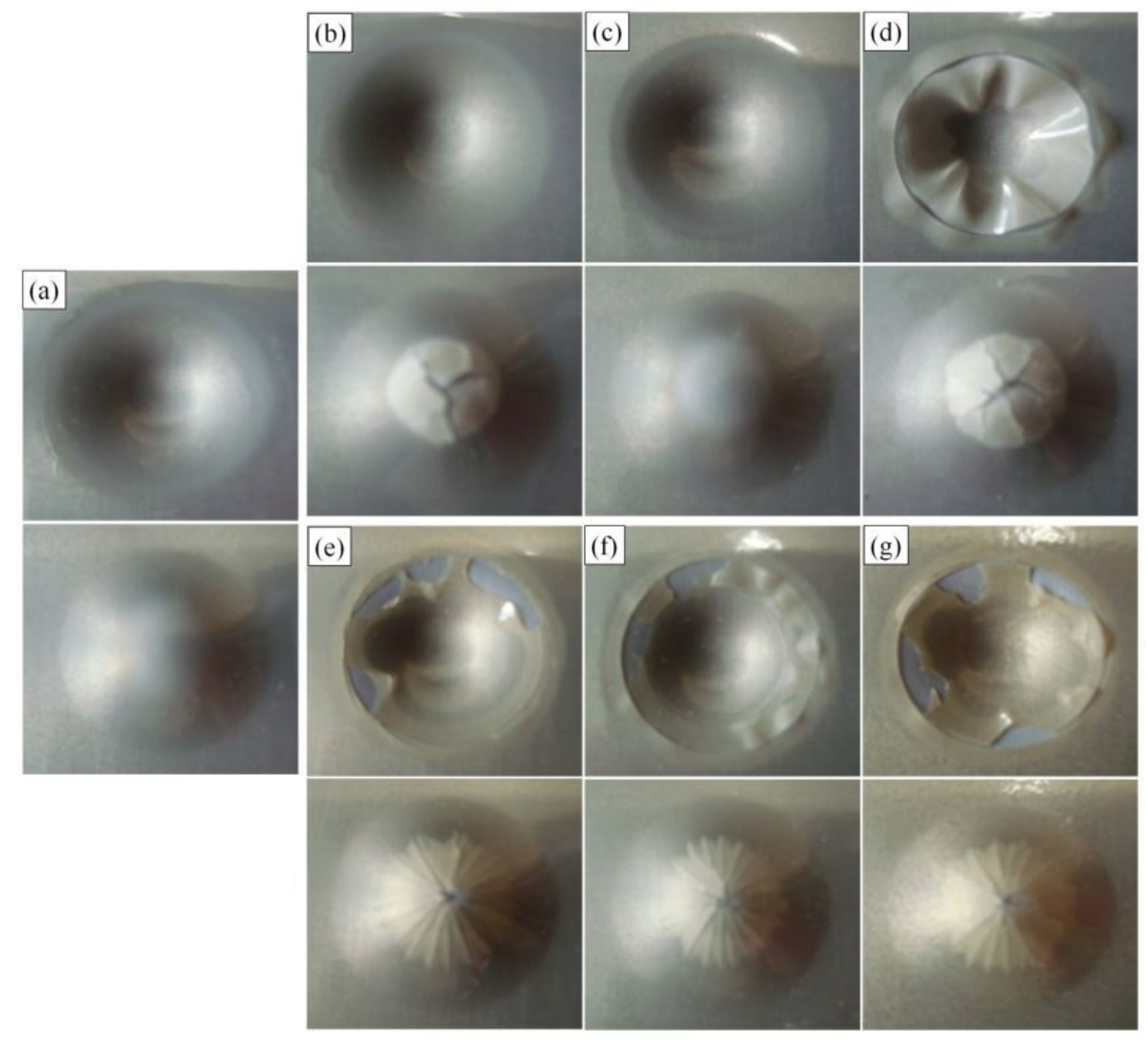

Figure 13. Images of the quick deformation resistance test (ASTM D2794) of paints based on epoxy / polyester powder coating after curing, and applied to mild steel panels: (a) TH/0, (b) TH/2/MICA, (c) TH/4/MICA, (d) TH/6/MICA, (e) TH/2/MMT 30B, (f) TH/4/MMT 30B e (g) TH/6/MMT 30B.

the presence of muscovite mica in the powder coating. The TH/2/MICA and TH/6/MICA samples presented a low resistance to impact deformation, cracks and spalling as seen in Figures $13 \mathrm{~b}$ and $13 \mathrm{~d}$. The increase of the muscovite mica concentration to $6 \mathrm{phr}$ may have favored the formation of clay agglomerates, resulting in a greater level of brittleness in the regions where cracks have occurred ${ }^{[63,64]}$. The coatings containing different concentrations of MMT 30B showed spalling and cracks in the direct and reverse impact. The lower impact resistance of these samples may be associated with an increased stiffness of the material that can be associated with the high aspect ratio of clay nanoparticles and to the decrease in the molecular mobility may have been caused by the restrictions imposed by an intercalation of epoxy and polyester resin molecules in the inside the MMT galleries. Piazza et al. ${ }^{[57]}$ have argued that the low resistance to deformation by impact of epoxy-based coatings containing different concentrations of MMT 30B are due to three factors: the formation of clay agglomerates which results in favorable fracture points; the increase in the stiffness of the material and the reduction of the reactivity and crosslink density. Other researchers analyzed the influence of MMT clay on epoxy base powder coating and found similar morphological results to those found in this article. The authors associated the fragility of the coatings to the characteristic stiffness of the predominantly exfoliated structure of the nanocomposites ${ }^{[64]}$, morphology is observed in the XRD diffractograms of the cured samples and corroborated in the micrographs obtained by transmission electron microscopy.

According to Mirabedini and Kiamanesh ${ }^{[55]}$ the presence of inorganic particles in the coating reduces the dissipation of energy, after the application of an external force causing the fracture of the coating.

The salt spray test evaluated the protection against corrosion performance in hybrid powder coatings with and without the addition of clay minerals. To perform this test were chosen coatings with better performance in thermal and mechanical tests. Figure 14 shows the appearance of the 

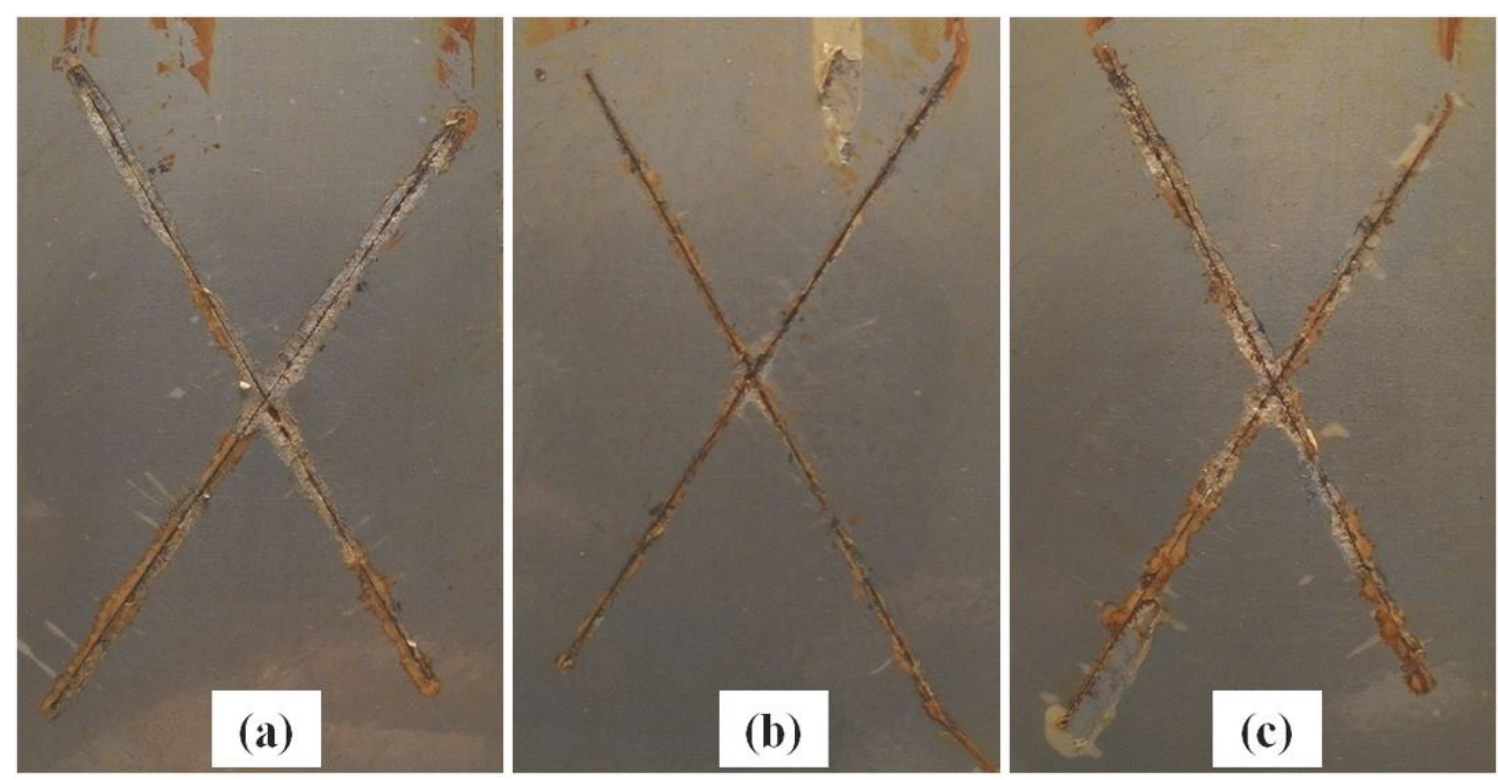

Figure 14. Images of the samples after 850 hours of exposure to the salt spray test (ASTM B117) (a) TH/0, (b) TH/4/MICA e (c) TH/2/MMT 30B.

exposed samples after 850 hours of salt spray, indicating the presence of corrosion products near the incision.

Neither blistering nor corrosion spots were observed on the surface of any of the samples, indicating the effectiveness of the barrier effect provided by the clays. The increased corrosion resistance is associated to the nature, form and size of the filler. Piazza et al. ${ }^{[10]}$ reported an increased barrier effect with the addition of MMT to a polyester-based powder coating. Ghoudalakis ${ }^{[6]}$ considered this effect to be due to the increase in the difficulty of diffusion (tortuosity) of liquid or gas molecules throughout the polymer film due to the predominantly exfoliated nanocomposite structure. The highest displacement values were verified for samples incorporating MMT 30B. This corroborates with the results of the mechanical tests (flexibility and impact) in which it was identified that the coatings incorporating MMT 30B presented inferior properties to the coatings with the addition of muscovite mica.

\section{Conclusions}

The thermal analyzes of TGA, DSC and FTIR showed that thermal stability of the coatings decreased when it was added clay mineral.

With the SEM-FEG analysis it was possible to identify that the muscovite mica has a lamellar structure and the MMT 30B shows irregular agglomerates consisting of relatively flat sheets.

Through the XRD analysis, an increase in the basal spacing was observed for the coatings with MMT 30B incorporation, predominating exfoliated phase for lower concentrations of clay and intercalation for coatings with higher concentrations of MMT 30B. For the muscovite mica coatings it was not possible to identify exfoliation or intercalation of the polymer matrix with the clay minerals.

The results of the mechanical characterization show that when the coating was subjected to a slow deformation (adhesion and flexibility) the incorporation of the clay did not affect the performance of the coatings. However, when an instantaneous force is applied, the coatings containing clays showed a peeling of the film. Thus, it can be considered that time is needed for the polymer and the clay to adjust to the mechanical deformation for the film not to be broken.

All the coatings with the addition of clay minerals presented corrosion performance similar to non-clayey coatings. None of the coatings showed blistering or corrosion spots on the surface.

\section{Acknowledgements}

The authors acknowledge the financial support of CAPES, the Laboratório de Polímeros (LPOL), the Laboratório de Corrosão of UCS (Corrosion Laboratory) for conducting mechanical tests, Pulverit for providing raw material and the Laboratório Central de Microscopia Prof. Israel Baumvol (Central Microscopy Laboratory) for the field emission scanning electron microscopy analisys.

\section{References}

1. Fazenda, J. M. R. (2009). Tintas: ciência e tecnologia. São Paulo: Blucher.

2. Mariz, I. F. A., Millichamp, I. S., Cal, J. C., \& Leiza, J. R. (2010). High performance water-borne paints with high volume solids based on bimodal latexes. Progress in Organic Coatings, 68(3), 225-233. http://dx.doi.org/10.1016/j.porgcoat.2010.01.008.

3. Kukackova, H., Vrastilová, A., \& Kalendova, A. (2013). Non-toxic anticorrosive pigments intended for applications 
in high-solids and waterborne paints. Physics Procedia, 44, 238-246. http://dx.doi.org/10.1016/j.phpro.2013.04.029.

4. Camargo, M. (2002). Resinas poliésteres carboxifuncionais para tinta em pó: caracterização e estudo cinético da reação de cura (Tese de doutorado). Universidade Federal do Rio Grande do Sul, Porto Alegre.

5. Gentil, V. (2011). Corrosão. Rio de Janeiro: LTC.

6. Mafi, R., Mirabedini, S. M., Naderi, R., \& Attar, M. M. (2008). Effect of curing characterization on the corrosion performance of polyester and polyester/epoxy powder coatings. Corrosion Science, 50(12), 3280-3286. http://dx.doi.org/10.1016/j. corsci.2008.08.037.

7. Rabello, M. (2011). Aditivação de polímeros. São Paulo: Artliber.

8. Tomic, M. D., Dunjic, B., Likic, V., Bajat, J., Rogan, J., \& Djonlagic, J. (2014). The use of nanoclay in preparation of epoxy anticorrosive coatings. Progress in Organic Coatings, 77(2), 518-527. http://dx.doi.org/10.1016/j.porgcoat.2013.11.017.

9. Liu, B., \& Wang, Y. (2014). A novel design for water-based modified epoxy coating with anti-corrosive application properties. Progress in Organic Coatings, 77(1), 219-224. http://dx.doi.org/10.1016/j.porgcoat.2013.09.007.

10. Piazza, D., Silveira, D. S., Lorandi, N. P., Birriel, E. J., Scienza, L. C., \& Zattera, A. J. (2012). Polyester-based powder coatings with montmorillonite nanoparticles applied on carbon steel. Progress in Organic Coatings, 73(1), 42-46. http://dx.doi. org/10.1016/j.porgcoat.2011.08.018.

11. Waschburger, M. R. (2006). Compósito de propileno com nanocarga (Dissertação de mestrado). Universidade Federal do Rio Grande do Sul, Porto Alegre.

12. Chen, C., Khobaib, M., \& Curliss, D. (2003). Epoxy layeredsilicate nanocomposites. Progress in Organic Coatings, 47(3-4), 376-383. http://dx.doi.org/10.1016/S0300-9440(03)00130-9.

13. Sebenik, G., Huskic, M., Vengust, D., \& Zigon, M. (2015). Properties of epoxy and unsaturated polyester nanocomposites with polycation modified montmorillonites. Applied Clay Science, 109-110, 143-150. http://dx.doi.org/10.1016/j. clay.2015.03.004.

14. Bongiovanni, R., Turcato, E. A., Di Gianni, A., \& Ronchetti, S. (2008). Epoxy coatings containing clays and organoclays: Effect of the filler and its water content on the UV-curing process. Progress in Organic Coatings, 62(3), 336-343. http:// dx.doi.org/10.1016/j.porgcoat.2008.01.014.

15. Hang, T.T.X., Truc, T. A., Nam, T. H., Oanh, V. K., Jorcin, J.-B., \& Pébère, N. (2007). Corrosion protection of carbon steel by an epoxy resin containing organically modified clay. Surface and Coatings Technology, 201(16-17), 7408-7415. http://dx.doi.org/10.1016/j.surfcoat.2007.02.009.

16. Hussain, F., Chen, J., \& Hojjati, M. (2007). Epoxy-silicate nanocomposites: cure monitoring and characterization. Materials Science and Engineering A, 445-446, 467-476. http://dx.doi. org/10.1016/j.msea.2006.09.071.

17. Salahuddin, N., Moet, A., Hiltner, A., \& Baer, E. (2002). Nanoscale highly filled epoxy nanocomposite. European Polymer Journal, 38(7), 1477-1482. http://dx.doi.org/10.1016/ S0014-3057(02)00015-0.

18. Carrasco, F., \& Pagés, P. (2008). Thermal degradation and stability of epoxy nanocomposites: Influence of montmorillonite content and cure temperature. Polymer Degradation \& Stability, 93(5), 1000-1007. http://dx.doi.org/10.1016/j. polymdegradstab.2008.01.018.

19. José, N. M., \& Prado, L. A. S. A. (2005). Materiais Híbridos Orgânico-Inorgânicos: Preparação e Algumas Aplicações. Quimica Nova, 28(2), 281-288. http://dx.doi.org/10.1590/ S0100-40422005000200020.
20. ASTM - American Society for Testing and Materials. (2010). ASTM D7378: standard practice for measurement of thicknen of applied coating powders to predict cured thickness. West Conshohocken: ASTM.

21. ASTM-American Society for Testing and Materials. (2005). ASTM D3363: standard test method for film hardness by pencil test (Reapproved 2011). West Conshohocken: ASTM.

22. ASTM - American Society for Testing and Materials. (2009). ASTM D 3359: standard test methods for measuring adhesion by tape test. West Conshohocken: ASTM.

23. ASTM - American Society for Testing and Materials. (2008). ASTM D 523: standard test method for specular gloss. West Conshohocken: ASTM.

24. ASTM-American Society for Testing and Materials. (1993). ASTM D522: standard test methods for mandrel bend test of attached organic coatings (Reapproved 2008). West Conshohocken: ASTM.

25. ASTM - American Society for Testing and Materials. (1993). ASTM D2794: standard test method for resistance of organic coatings to the effects of rapid deformation (impact) (Reapproved 2010). West Conshohocken: ASTM.

26. ASTM - American Society for Testing and Materials. (2007). ASTM B117: standard practice for operating salt spray (fog) apparatus. West Conshohocken: ASTM.

27. Paiva, L. B., Morales, A. R., \& Díaz, F. R. V. (2008). Argilas organofílicas: características, metodologias de preparação, compostos de intercalação e técnicas de caracterização. Cerâmica, 54(330), 213-226. http://dx.doi.org/10.1590/S036669132008000200012.

28. Hull, T. R., Witkowski, A., \& Hollingbery, L. (2011). Fire retardant action of mineral fillers. Polymer Degradation \& Stability, 96(8), 1462-1469. http://dx.doi.org/10.1016/j. polymdegradstab.2011.05.006.

29. Sirelli, L. (2008). Compósitos de poli(tereftalato de etileno) $e$ mica muscovita: preparação, caracterização e propriedades (Tese de doutorado). Universidade Federal do Rio de Janeiro, Rio de Janeiro.

30. Lakshmi, M. S., Narmadha, B., \& Reddy, B. S. R. (2008). Enhanced thermal stability and structural characteristics of different MMT-Clay/epoxy-nanocomposite materials. Polymer Degradation \& Stability, 93(1), 201-213. http://dx.doi. org/10.1016/j.polymdegradstab.2007.10.005.

31. Bharadwaj, R. K., Mehrabi, A. R., Hamilton, C., Trujillo, C., Murga, M., Fan, R., Chavira, A., \& Thompson, A. K. (2002). Structure property relationships in cross-linked polyester-clay nanocomposites. Polymers, 43(13), 3699-3705. http://dx.doi. org/10.1016/S0032-3861(02)00187-8.

32. Oliveira Júnior, A. R. (2006). Obtenção de nanocompósitos polipropileno-argila compatibilizados com organossilanos (Tese de doutorado). Universidade Estadual de Campinas, Campinas.

33. Ollier, R., Rodriguez, E., \& Alvarez, V. (2013). Unsaturated polyester/bentonite nanocomposites: Influence of clay modification on final performance. Composites. Part A, Applied Science and Manufacturing, 48, 137-143. http://dx.doi.org/10.1016/j. compositesa.2013.01.005.

34. Kim, S., \& Wilkie, C. A. (2008). Transparent and flame retardant PMMA nanocomposites. Polymers for Advanced Technologies, 19(6), 496-506. http://dx.doi.org/10.1002/pat.1089.

35. Mansoori, Y., Akhtarparast, A., Zamanloo, M. R., Imanzadeh, G., \& Masooleh, T. M. (2011). Polymer-montmorillonite nanocomposites: Chemical grafting of polyvinyl acetate onto Cloisite 20A. Polymer Composites, 46(8), 1844-1853.

36. Gu, A., \& Liang, G. (2003). Thermal degradation behaviour and kinetic analysis of epoxy/montmorillonite nanocomposites. 
Polymer Degradation \& Stability, 80(2), 383-391. http://dx.doi org/10.1016/S0141-3910(03)00026-0.

37. Kalenda, P., Kalendová, A., Stengl, V., Antos, P., Subrt, J., Kvaca Z., \& Bakardjieva, S. (2004). Properties of surface-treated mica in anticorrosive coatings. Progress in Organic Coatings, 49(2), 137-145. http://dx.doi.org/10.1016/j.porgcoat.2003.09.003.

38. Le, S., Sun, K., Zhang, N., Shao, Y., An, M., Fu, Q., \& Zhu, X. (2007). Comparison of infiltrated ceramic fiber paper and mica base compressive seals for planar solid oxide fuel cells Journal of Power Sources, 168(2), 447-452. http://dx.doi. org/10.1016/j.jpowsour.2007.03.014.

39. Moate, B. D., \& Thorne, P. D. (2012). Interpreting acoustic backscatter from suspended sediments of different and mixed mineralogical composition. Continental Shelf Research, 46, 67-82. http://dx.doi.org/10.1016/j.csr.2011.10.007.

40. Gacitua, E. W., Ballerini, A. A., \& Zhang, J. (2005). Polymer nanocomposites: synthetic and natural fillers. Maderas. Ciencia y Tecnología, 7(3), 159-178.

41. Pukánszky, B. (2005). Interfaces and interphases in multicomponent materials: past, present, future. European Polymer Journal, 41(4), 645-662. http://dx.doi.org/10.1016/j. eurpolymj.2004.10.035.

42. Wang, Z., Han, E., \& Ke, W. (2006). Effect of nanoparticles on the improvement in fire-resistant and anti-ageing properties of flame-retardant coating. Surface and Coatings Technology, 200(20-21), 5706-5716. http://dx.doi.org/10.1016/j. surfcoat.2005.08.102.

43. Reichert, P., Nitz, H., Klinke, S., Brandsch, R., Thomann, R., \& Mulhaupt, R. (2000). Poly(propylene)/organoclay nanocomposite formation: Influence of compatibilizer functionality and organoclay modification. Macromolecular Materials and Engineering, 275(1), 8-17. http://dx.doi.org/10.1002/(SICI)14392054(20000201)275:1<8::AID-MAME8>3.0.CO;2-6.

44. Duncan, T. V. (2011). Applications of nanotechnology in food packaging and food safety: barrier materials, antimicrobials and sensors. Journal of Colloid and Interface Science, 363(1), 1-24. http://dx.doi.org/10.1016/j.jcis.2011.07.017. PMid:21824625.

45. Hetzer, M., \& Kee, D. (2008). Wood/polymer/nanoclay composites, environmentally friendly sustainable technology: a review. Chemical Engineering Research \& Design, 86(10), 1083-1093. http://dx.doi.org/10.1016/j.cherd.2008.05.003.

46. Zulfiqar, S., Kausar, A., Rizwan, M., \& Sarwar, M. I. (2008). Probing the role of surface treated montmorillonite on the properties of semi-aromatic polyamide/clay nanocomposites. Applied Surface Science, 225(5), 2080-2086. http://dx.doi. org/10.1016/j.apsusc.2008.06.184.

47. Paul, D. R., \& Robeson, L. M. (2008). Polymer nanotechnology: nanocomposites. Polymer, 49(15), 3187-3204. http://dx.doi. org/10.1016/j.polymer.2008.04.017.

48. Pavlidou, S., \& Papaspyrides, C. D. (2008). A review on polymer-layered silicate nanocomposites. Progress in Polymer Science, 33(12), 1119-1198. http://dx.doi.org/10.1016/j. progpolymsci.2008.07.008.

49. Paiva, L. B., Morales, A. R., \& Díaz, F. R. V. (2008). Organoclays: properties, preparation and applications. Applied Clay Science, 42(1-2), 8-24. http://dx.doi.org/10.1016/j.clay.2008.02.006.

50. Bikiaris, D. (2011). Can nanoparticles really enhance therma stability of polymers? Part II: An overview on thermal decomposition of polycondensation polymers. Thermochimica Acta, 523(1-2), 25-45. http://dx.doi.org/10.1016/j.tca.2011.06.012.

51. Huskic, M., Zigon, M., \& Ivankovic, M. (2013). Comparison of the properties of clay polymer nanocomposites prepared by montmorillonite modified by silane and by quaternary ammonium salts. Applied Clay Science, 85, 109-115. http:// dx.doi.org/10.1016/j.clay.2013.09.004.
52. Lee, W.-F., \& Chen, Y.-C. (2005). Effect of intercalated reactive mica on water absorbency for poly(sodium acrylate) composite superabsorbents. European Polymer Journal, 41(7), 1605-1612. http://dx.doi.org/10.1016/j.eurpolymj.2005.02.011.

53. Rashid, E. S. A., Rasyid, M. F. A., Akil, H. M. D., Ariffin, K., \& Kooi, C. C. (2011). Effect of ion exchange treatment on the properties of muscovite filled epoxy composite. Applied Clay Science, 52(3), 295-300. http://dx.doi.org/10.1016/j. clay.2011.03.008.

54. Choi, J., Komarneni, S., Grover, K., Katsuki, H., \& Park, M. (2009). Hydrothermal synthesis of Mn-mica. Applied Clay Science, 46(1), 69-72. http://dx.doi.org/10.1016/j.clay.2009.07.014.

55. Mirabedini, S. M., \& Kiamanesh, A. (2013). The effect of micro and nano-sized particles on mechanical and adhesion properties of clear polyester powder coating. Progress in Organic Coatings, 76(11), 1625-1632. http://dx.doi.org/10.1016/j. porgcoat.2013.07.009.

56. Lv, S., Zhou, W. Z., Li, S., \& Shi, W. (2008). A novel method for preparation of exfoliated UV curable polymer/clay nanocomposites. European Polymer Journal, 44(6), 16131619. http://dx.doi.org/10.1016/j.eurpolymj.2008.04.005.

57. Piazza, D., Lorandi, N. P., Pasqual, C. I., Scienza, L. C., \& Zattera, A. J. (2011). Influence of a microcomposite and a nanocomposite on the properties of an epoxy-bases powder coating. Materials Science and Engineering A, 528(22-23), 6769-6775. http://dx.doi.org/10.1016/j.msea.2011.05.062.

58. Bagherzadeh, M. R., \& Mahdavi, F. (2007). Preparation of epoxy-clay nanocomposites andinvestigation on its anti-corrosive behavior in epoxy coating. Progress in Organic Coatings, 60(2), 117-120. http://dx.doi.org/10.1016/j.porgcoat.2007.07.011.

59. Navarchian, A. H., Joulazadeh, M., \& Karimi, F. (2014). Investigation of corrosion protection performance of epoxy coatings modified by polyaniline/clay nanocomposites on steel surfaces. Progress in Organic Coatings, 77(2), 347-353. http://dx.doi.org/10.1016/j.porgcoat.2013.10.008.

60. García, S. J., Serra, A., \& Suay, J. (2007). New powder coatings with low curing temperature and enhanced mechanical properties obtained from DGEBA epoxy resins and meldrum acid using erbium triflate as curing agent. Journal of Polymer Science. Part A, Polymer Chemistry, 45(11), 2316-2327. http://dx.doi. org/10.1002/pola.21998.

61. Bertuoli, P. T. (2014). Desenvolvimento e caracterização de uma tinta em pó base poliéster contendo montmorilonita funcionalizada com silano (Dissertação de mestrado). Universidade de Caxias do Sul, Caxias do Sul

62. Wicks Júnior, W. Z. W., Jones, F. N., Pappas, S. P., \& Wicks, D. A. (2007). Organic coatings: science and technology. New Jersey: John Wiley \& Sons.

63. Dong, Y., Chaudhary, D., Ploumis, C., \& Lau, K. T. (2011). Correlation of mechanical performance and morphological structures of epoxy micro/nanoparticulate composites. Composites. Part A, Applied Science and Manufacturing, 42(10), 1483-1492. http://dx.doi.org/10.1016/j.compositesa.2011.06.015.

64. Akbari, B., \& Bagheri, R. (2007). Deformation mechanism of epoxy/clay nanocomposite. European Polymer Journal, 43(3), 782-788. http://dx.doi.org/10.1016/j.eurpolymj.2006.11.028.

65. Choudalakis, G., \& Gotsis, A. D. (2009). Permeability of polymer/ clay nanocomposites: A review. European Polymer Journal, 45(4), 967-984. http://dx.doi.org/10.1016/j.eurpolymj.2009.01.027.

Received: Mar: 07, 2016

Revised: Sept. 20, 2017

Accepted: Dec. 14, 2017 